\title{
Kearifan Lokal Perguruan Tinggi Menghadapi Liberalisasi Pendidikan
}

\author{
Djohar MS
}

The presenting of foreign universities in Indonesia will become an interesting and challeng phenomenon. If this happens, many Indonesian people will enter the foreign universities although the education cost expensive because of the advancing or development. In thsis sense, the academic institutions denote comercial institution. Hence, the image of the scientificity tends to become unclear, on one hand Indonesia has the institution to develop science and technology, and on the other Indonesia does not pay attention to sicence and technology. The liberalization of education implies to Indonesian system of education which each institution moves based on its interest.

Kata Kunci: kearifan lokal, liberalisasi, pendidikan,kompetisi

T erhadap masalah yang kita hadapi ini saya tidak memandang dari dimensi ekonomi, akan tetapi saya pandang dari posisi Perguruan Tinggi (PT) sebagai lembaga ilmu. Sehingga sudut pandang pemecahan masalahnya akan saya lihat dari sisi itu. Pemahaman kearifan local PT kita fokuskan kepada kearifan. Perguruan Tinggi kita secara mandiri dalam menyikapi ilmu, teknologi dan pengembangannya. Pada dasamya, bagaimana kita menyelenggarakan Perguruan Tinggi saat ini? Bila kita tempatkan PT sebagai lembaga ilmu, maka apa konsekuensinya? Kita seharusnya memahami benar kondisi lokal kita masing-masing, sehingga kita dapat dengan proporsional menempatkan bagaimana menyelenggarakan PT kita. Bila kita perhatikan kedudukan Perguruan Tinggi dinegara kita, maka kita masih menempatkan Perguruan Tinggi kita sebagai lembaga pendidikan. Sebenarnya apabila kita memperhatikan struktur jenjang pendidikan kita, maka masing-masing jenjang dapat dikategorikan sebagai berikut:

1. SD dan SMP sebagai jenjang pendidikan dasar "wajib belajar" berfungsi utuh mengembangkan pendidikan, yang terkait dengan kepentingan bangsa dalam menyikapi bagaimana pendidikan dasar dapat menyiapkan anak-anak kita memiliki kompetensi perilaku Pancasila, memiliki kompetensi hidup dalam bangsa yang multikultural, memiliki kompetensi hidup dalam kondisi bangsa yang berbeda agama, dll

2. SMA sebagai jenjang pendidikan lanjutan, maka memiliki tugas $50 \%$ menyelenggarakan pendidikan dan $50 \%$ menempatkan diri sebagai lembaga pengkaji ilmu, minimal sebatas fungsi konservasi ilmu pengetahuan, dengan secara sporadis juga terlibat dalam pengembangan ilmu sebagai fungsi pendidikan, dan sekaligus mengembangkan metodologi keilmuan. 
3. PT adalah $100 \%$ sebagai lembaga ilmu, dalam fungsi tidak sekedar fungsi konservasi tetapi juga dalam fungsi pengembangan ilmu pengetahuan dan teknologi.

4. Lembaga pendidikan lain misainya lembaga pendidikan komputer yang menyiapkan para pesertanya untuk trampil mengendalikan komputer, dan lembaga lain yang menjamin terjadinya pendidikan seumur hidup bagi masyarakat.

Sehingga kompetensi lulusan setiap jenis dan jenjang pendidikan kita jelas, yang memudahkan masyarakat merekrut mereka dalam lapangan kerja sesuai dengan kompetensi yang dibutuhkan.

Sayangnya dalam kenyataannya sekarang PT masih diposisikan sebagai lembaga pendidikan. Maka pertanyaannya adalah siapa yang bertugas mengembangkan dan mengkonservasi ilmu pengetahuan dan teknologi?. Lebih-lebih dalam era kompetisi yang semakin substansial ini. Bahkan saat ini Undangundang guru telah disatukan dengan dosen. Pengembangan ilmu kita gelap. Sampai saat ini kita masih menempatkan PT sebagai lembaga pendidikan. Dengan demikian maka pada saat ini apabila ilmu dan teknologi kita tidak berkembang sangatlah wajar. Atas dasar sudut pandang tinjauan itu maka kita akan melihat kearifan local kita dalam menyikapi ilmu itu terabaikan. Bila kita berpikir kekuatan, kelemahan, peluamg, dan ancaman tentang kajian keilmuan kita yang terjadi di negara kita, jelas jika kita akan menghadapi ancaman atas tidak berkembangnya ilmu dan teknologi di negara kita. Berarti kearifan local kita dalam mengelola PT terhadap arus liberalisasi akan berada di pihak yang lemah dan kalah. Dengan demikian maka apabila kita mengenal kondisi local kita, maka kita dapat menyikapi keberadaan Perguruan Tinggi di dalamnya secara proporsional, dan kita akan memaklumi apa yang akan terjadi di negara kita.

Apabila kita perhatikan dengan jeli, tampaknya PT kita belum banyak tahu tentang kondisi local kita itu. Kita maklum akan terjadinya kompetisi dalam era liberalisasi, tetapi kita tidak menyiapkan substansi untuk berkompetisi. Hal ini dapat dimengerti karena kita belum melaksanakan "iqra'". Padahal "iqra' " adalah cara mengkaji ciptaan Tuhan untuk memperoleh ilmu Tuhan. Pada dasamya melaksanakan "iqra" adalah mengkaji realita Tuhan di bumi ini. Kita sekarang belum mengkaji realita, yang kita kaji adalah buku karya."iqra"' bangsa lain.. Padahal buku seharusnya berfungsi sebagai referensi dan untuk konservasi ilmu pengetahuan. Memberi petunjuk apa yang yang telah kita ketahui dan apa yang telah kita teliti. Kita belum mampu membangun ilmu. Bila kita tidak memiliki lembaga keilmuan bagaimana masa depan bangsa kita dalam dunia ilmu dan teknologi kita. Maka kita akan menjadi bangsa yang sangat tergantung di bidang ilmu dan teknologi kepada bangsa lain. Dengan PT menjadi lembaga pendidikan, maka pendidikannya tidak didapat, juga ilmunya tidak dapat dicapai, akhirnya semuanya ketinggalan. Yang dikejar adalah jumlah mahasiswa.

Bukti dari kenyataan itu dapat terlihat jelas, di setiap PT kita masih terjadi keadaan sebagai berikut:

1. Kajian realita masih sangat langka

2. Kerja dan pengadaan laboratorium belum menjadi prioritas

3. Keberadaan laboratorium sekedar sebagai pelengkap

4. Laboratorium berfungsi verifikasi, atau penerapan teori bukan sebagai sarana untuk membangun konsep 


\section{Secara keseluruhan orientasi belajar kita belum menyentuh realita \\ 6. Orientasi pemebelajaran kita masih tekstual}

7. Bahkan kita tidak memiliki pemahaman realita, segalanya dipecahkan dari teori, meskipun mungkin tidak berlaku bagi bangsa kita.

Kita belum mampu membangun ilmu pengetahuan sendiri yang universal, kita terlalu mengandalkan kepada ilmu pengetahuan orang lain, kita sangat tekstual. Buku-buku keilmuan yang beredar sangat langka menggunakan temuan bangsa kita. Belum diprioritaskan prasarana seperti disebutkan di atas, maka menunjukkan apabila kita masih arif terhadap potensi asing, belum tumbuh kearifan lokal kita.

Pendidikan di PT seharusnya terfokus kepada pembangunan pribadi yang memiliki budaya ilmu, mampu memecahkan masalah dengan meneliti sesuai metodologi ilmunya, mampu mengkonseptualisasikan, mampu menggali ilmu mengikuti ujung tombak perkembangannya.

Padahal budaya ilmu di luar telah masuk ke dalam kegiatan :

1. Mengkaji realita

2. Konseptualisasi untuk membangun konsep

3. Mengembangkan keilmuan menurut ujung tombak perkembangannya

4. Temuan baru digunakan sebagai isi pengembangan buku

5. Buku dimanfaatkan sebagai alat konservasi ilmu pengetahuan dan sebagai referensi kajian

6. Hanya limu Dasar yang dibangun dari buku

Di negara kita llmu dasar dan pengembanganpun masih tekstual.

\section{Kearifan lokal}

Negara kita sangat kaya SDA (Sumber Daya Alam). Kita tidak pernah sentuh SDA kita dengan teknologi kita sendiri, kita mengandalkan teknologi dari luar. Bahkan pihak luar telah tahu peta kekayaan kita, tetapi kita belum mengetahuinya.

Perguruan Tinggi kita yang masih diposisikan sebagai lembaga pendidikan maka penelitian yang dilakukanpun sekedar berwacana pendidikan penelitian, dengan berbagai katagorinya. Penelitian hanya untuk pendidikan penelitian, dan menghasilkan diskusi dalam ruangan, tetapi di luar ruangan hasilnya belum bermakna apa-apa baik bagi ilmu maupun bagi kehidupan. Produk-produk penelitian kita masih langka yang memberikan kontribusi keilmuan. Penelitian kita belum merupakan ujung tombak pengembangan ilmu, dan hasilnya belum mampu mengisi atau mengkontribusi terhadap terbentuknya bangun keilmuan atau belum membangun badan ilmu.

Objektivitas kita belum memiliki kearifan lokal yang kita andalkan, dan selama PT kita posisikan sebagai lembaga pendidikan maka kearifan local kita di bidang ilmu dan teknologi semakin mundur. Kebijakan yang kita lakukan lebih ke arah kebijakan administratif dari pada akademik ilmu. Sehingga posisi lokalitas kita berada dalam posisi ancaman. Masalahnya mampukah kita mengubah ancaman menjadi peluang? Tergantung pada kreativitas kita.

Masalah yang paling mendasar ialah kita tidak pernah melihat objektivitas itu, sehingga kita memilih dalam posisi stationer. Kegelapan di masa datang tidak dicari di mana ada lilin menyala, tetapi kita biarkan tetap gelap. Kita lebih senang membesarbesarkan bara yang saat ini menyala tetapi mungkin akan mati lima tahun ke depan, dari pada mencermati lilin yang menjadi petunjuk bahkan akan menjadi bara di masa datang. 
Kita memiliki tipe budaya berfikir masa lampau. Sangat ramai bila membicarakan masa lampau tetapi diam bila memikirkan masa datang. Sehingga kearifan lokal kita terhalang oleh budaya kita sendiri.

Tidakarifnya PT kita terhadap objektivitas itu yakni ditandai oleh gerak PT yang berlomba mencari Mahasiswa. Kapan research university akan terwujud?

\section{Liberalisasi Pendidikan}

Sesaat lagi PT asing masuk ke Indonesia. Saat ini telah dimulai dari sekolahsekolah asing. Berapa banyak anak-anak kita yang studi di luar Indonesia meskipun mahal, dapat digunakan sebagai cermin, bagaimana PT asing di negara kita akan diserbu oleh masyarakat yang menghendaki kemajuan. Dibanding studi di luar Indonesia, maka studi di PT Internasional di Indonesia akan lebih murah.

Bagaimanapun bentuknya lembaga akademik saat ini telah menjadi lembaga komersial. Oleh karena itu citra keilmuan kita semakin lama semakin tidak menentu, di satu sisi kita tidak memiliki lembaga untuk menangani bidang ilmu dan teknologi, dan di sisi lain kita tidak memiliki perhatian terhadap bidang ilmu dan teknologi. Mendirikan PT asing di negara kita tampak tidak begitu sulit, karena PT asing bila menyelenggarakan kegiatan di Indonesia syaratnya hanyalah harus bekerjasama dengan PT dalam negeri, padahal kita memiliki banyak PT yang dapat diajak kerjasama.

Liberalisasi pendidikan kenyataannya juga telah menjangkit system pendidikan di Indonesia. Masing-masing lembaga pendidikan bergerak menurut kemaunnnya sendiri. Bentuk-bentuk kebersamaan meskipun menguntungkan masyarakat justru ditinggalkan, yang dikejar adalah sys- tem yang menguntungkan lembaga diri sendiri.

\section{Usaha}

Usaha apa yang harus kita lakukan, ialah dengan membangun kerjasama antar PT di Indonesia, justru tidak jegal-jegalan seperti sekarang ini. Minimal kita menjalankan PT kita masing-masing dengan wajar, tidak merugikan PT yang lain. Hargailah hakhak orang lain. Kita perbaiki mekanisme kerja antara Yayasan dan PT masingmasing, dengan diwujudkan adanya satu gerak bersama, saling mengisi, saling mendukung untuk kemajuan. Selain menggunakan pengendalian akademik juga menggunakan pengendalian bisnis, dengan mempertimbangkan efisiensi, efektivitas, kehati-hatian yang ada dasarnya, memiliki keberanian ke depan dengan penuh perhitungan, dan menggunakan prinsip gotong royong. Kita harus membangun kerjasama dengan pihak manapun yang menguntungkan.

\section{Kompetisi}

Pola kompetisi yang kita lakukan seharusnya adalah kompetisi kualitatif akademik, bukan kompetisi kauntitatif, dengan meningkatkan wacana kita, personalitas (SDM) kita, dan dengan peningkatan perencanaan dan disiplin kita untuk melaksanakannya. Menerapkan prisip "Total Quality Control", dengan menerapkan prinsip kerja:

1. Melembaga, artinya segala usaha kita demi untuk kepentingan lembaga, bukan untuk mencari keuntungan sendiri

2. Partisipasi integrative, artinya semua usaha kita demi kesuksesan program lembaga 


\section{$\therefore \quad, \cdots$,}

Kearifan Lokal Perguruan Tinggi Menghadapi Liberasasi Pendidikan; Djohar MS

3. Kepastian hukum, artinya kita mengacu kepada aturan main

4. Bijaksana dalam melaksanakan hukum, artinya kita tidak melaksanakan hukum itu secara mati, secara kaku sehingga malah menimbulkan kenugian diberbagai pihak

5. Kejelasan dalam status dan fungsi birokrasi, artinya kita tidak usah harus mencampuri pekerjaan yang telah menjadi tanggung jawab orang lain, walaupun bidang yang menjadi tanggung jawabnya termasuk kering Dengan menerapkan etika kerja (3K):

1. Kepedulian, dengan menegakkan hak orang lain

2. Keterbukaan, kita bekerja tanpa adanya rahasia, semua pihak boleh mengetahuinya, dengan kinerja dan pertanggung jawaban yang dapat diketahu dan dikontrol oleh semua pihak

3. Kebersamaan, sebagai akibat dari dua macam etika sebelumnya, sehingga di antara kita tidak ada rasa cemburu, rasa iri dan lain sebagainya, sehingga kita secara iklas berada dalam posisi horizontal, bersama-sama.

\section{Daftar Pustaka}

Tilaar, H. A. R. 1999. Pendidikan Kebudayaan dan Masyarakat Madani Indonesia. PT. Remaja Rosdakarya. Bandung

UNESCO. 1981. Bunuh Diri atau Hidup Selamat, Tantangan Tahun 2000. Gunung Agung Jakarta 